\title{
Reactions of Proton-Bound Dimers
}

\author{
Wan Yong Feng, Moshe Goldenberg, and Chava Lifshitz* \\ Department of Physical Chemistry and The Fritz Haber Research Center for Molecular Dynamics, \\ The Hebrew University of Jerusalem, Jerusalem 91904, Israel
}

\begin{abstract}
Thermal reactions of proton-bound dimers, $\left(\mathrm{CH}_{3} \mathrm{CN}\right)_{2} \mathrm{H}^{+},\left(\mathrm{CH}_{3} \mathrm{OCH}_{3}\right)_{2} \mathrm{H}^{+}$, and $\left(\mathrm{CH}_{3} \mathrm{COCH}_{3}\right)_{2} \mathrm{H}^{+}$, were studied using a selected ion flow tube. Reactions observed include association, switching, and proton transfer. The association channel was observed only for base molecules that had hydrogen bonding protons such as $\mathrm{NH}_{3}, \mathrm{CH}_{3} \mathrm{NH}_{2},\left(\mathrm{CH}_{3}\right)_{2} \mathrm{NH}$, and $\mathrm{CH}_{3} \mathrm{OH}$. An association-insertion mechanism was proposed in which the central proton of the symmetrically bound dimers is replaced by a protonated base, for example, $\mathrm{NH}_{4}^{+}$. These reactions are relatively slow, which demonstrates a central barrier along the potential energy surface. Ether-containing dimers do not demonstrate this insertion reaction, except for diethers, for example, $\mathrm{CH}_{3} \mathrm{OCH}_{2} \mathrm{CH}_{2} \mathrm{OCH}_{3}$, which can form stable bicyclic structures. Dimers such as $(\mathrm{HCOOH})_{2} \mathrm{H}^{+}$, which possess hydrogen bonding protons in the periphery, undergo switching reactions with ammonia and no insertion. (J Am Soc Mass Spectrom 1994, 5 , 695-703)
\end{abstract}

$\mathrm{H}$ Yydrogen-bonded structures, which are characterized by the symmetric positioning of molecules around a central proton or protonated molecule, possess special stability. Ion-molecule reactions of such species are of interest because they bridge the gap between gas-phase and liquid-solution-phase chemistry. Proton transfer reactions of $\left(\mathrm{H}_{2} \mathrm{O}\right)_{M} \mathrm{H}^{+}$with ammonia have shown [1] that the dominant channel is the least exothermic path that occurs by sequential loss of water molecules. The reaction of proton-bound methanol dimers with methanol was found [2] to proceed by association with no evidence for displacement, although the latter reaction is exothermic. Displacement requires $\mathrm{CH}_{3} \mathrm{OH}$ transfer from reactant to product ion, and quenching is consistent with a barrier to this transfer [2]. Other reactions were observed [3] for which $\Delta H^{\circ}>0$, but $\Delta G^{\circ}<0$. Our group has been interested recently in reactions of those species that also demonstrate abundance maxima (so-called magic numbers) in cluster sequences. As part of this research effort, we studied reactions of $\left(\mathrm{CH}_{3} \mathrm{OH}\right)_{3} \mathrm{H}^{+}$with a series of base molecules [4]. Observed reactions depended on the basicity of the neutral reactant and ranged from ligand switching, which forms a mixed trimer, through ligand switching and evaporation of a single methanol molecule, which formed a mixed dimer, to ligand switching and evaporation of two methanol molecules, which leads for molecules of the highest basicity, to the protonated

Address reprint requests to Professor Chava Lifshitz, Chemistry Department, Hebrew University of Jerusalem, Givat Ram, Jerusalem 91904, Israel.

*Archie and Marjorie Sherman Professor of Chemistry. base. An additional channel observed for the molecules of lowest basicity in the series was ligand association.

In the protonated methanol trimer; two methanol molecules are symmetrically positioned around protonated methanol. In the present study we concentrated on proton bound dimers in which two molecules are symmetrically positioned around the central proton, with special emphasis on ion-molecule reactions of $\left(\mathrm{CH}_{3} \mathrm{CN}\right)_{2} \mathrm{H}^{+},\left(\mathrm{CH}_{3} \mathrm{COCH}_{3}\right)_{2} \mathrm{H}^{+}$, and $\left(\mathrm{CH}_{3} \mathrm{OCH}_{3}\right)_{2} \mathrm{H}^{+}$. These dimers are particularly stable because they do not possess hydrogens that can form stable hydrogen bonding networks beyond the dimer. The special stability of some of these dimers has been demonstrated by ab initio calculations [5-7]. Other dimers, for example, $\left(\mathrm{CH}_{3} \mathrm{OCH}_{3}\right)_{2} \mathrm{H}^{+}$, are known from gas-phase ion equilibria studies [8] and multiphoton ionization of neutral clusters formed by supersonic expansions [9]. Cluster ionization and fragmentation [10] has demonstrated that although there are higher proton-bound clusters $\left(\mathrm{CH}_{3} \mathrm{CN}\right)_{n} \mathrm{H}^{+}$, no further closed shell is visible beyond the first shell for $n=2$. Steric hindrance was invoked as the cause for the reduced abundance of the trimer compared to the dimer in acetone [5], dimethyl ether [11], and also acetaldehyde [12] because the third molecule has to bind in a Tshaped structure [5] to the preexisting $\mathrm{O}-\mathrm{H}-\mathrm{O}$ bridge site. The linear structure was found to be more stable than the T-shaped structure [7] for the protonated acetonitrile trimer.

The thermochemistry, that is, $\Delta H^{\circ}, \Delta G^{\circ}$, and $\Delta S^{\circ}$ of clustering reactions, is known for acetonitrile [7], acetone [13], and dimethyl ether [13]. There has been a reevaluation of the upper proton affinity range recently [14], but the reference value for $i-\mathrm{C}_{4} \mathrm{H}_{8}$ is now being 
revised downward by $4 \mathrm{kcal} / \mathrm{mol}$ and the use of proton affinities from ref 15 is still recommended. The best literature data are summarized in Table 1.

Acetonitrile and acetone have been detected by rocket-borne, balloon-borne, and aircraft-borne mass spectrometry as part of the nonproton hydrate (NPH) ion families of the stratosphere and troposphere [16, 17]. Ion-molecule reactions of protonated bases of atmospheric importance were studied before [18] by using a selected ion flow tube (SIFT). Exothermic proton transfers, for example, from $\left(\mathrm{CH}_{3} \mathrm{CN}\right) \mathrm{H}^{+}$to $\mathrm{CH}_{3} \mathrm{COCH}_{3}$, were observed to be fast and to proceed at near collision rates. When proton transfers were endothermic, the overall reactions were considerably slower and governed by association. Solvation effects on ion-molecule reactions are of considerable interest $[1-3,19,20]$. A reduction in reactivity upon hydration of closed-shell ions usually has been observed. It is of interest to compare the reactivity of protonated dimers with that of the corresponding protonated monomers.

In the present study we reacted the protonated dimers of acetonitrile, dimethyl ether, and acetone with a series of base molecules with increasing proton affinities (PA) by using the SIFT. Reactivities and branching ratios are presented for these reactions and the results are discussed. A novel type of association-insertion mechanism is proposed. A series of reactions of different protonated dimers with ammonia is presented as a check for the proposed mechanism.

\section{Experimental}

The SIFT apparatus employed has been described in detail elsewhere [21]. Briefly, reactant ions are generated in a suitable ion source, are mass-selected by a quadrupole mass fitter, and injected into the flow tube by a helium carrier gas via a Venturi inlet. A neutral reactant is introduced into the flow tube at an appropriate distance downstream to ensure laminar flow. A detector quadrupole filter analyzes the reactant and product ions.

We were unable to inject the protonated dimers from the ion source into the flow tube. We injected the protonated monomers $\left(\mathrm{CH}_{3} \mathrm{CN}\right) \mathrm{H}^{+},\left(\mathrm{CH}_{3} \mathrm{OCH}_{3}\right) \mathrm{H}^{+}$,

Table 1. Thermochemistry of the stepwise dimerization reactions a: $\mathrm{H}^{+}+\mathrm{A} \rightarrow \mathrm{AH}^{+}$and $\mathrm{b}: \mathrm{AH}^{+}+\mathrm{A} \rightarrow \mathrm{A}_{2} \mathrm{H}^{+}$ ( $\mathrm{kcal} / \mathrm{mol}$ at $298 \mathrm{~K})$

\begin{tabular}{lcrr}
\hline \multicolumn{1}{c}{ A } & Reaction & \multicolumn{1}{c}{$\Delta H^{\circ}$} & \multicolumn{1}{c}{$\Delta G^{\circ}$} \\
\hline \hline $\mathrm{CH}_{3} \mathrm{CN}$ & a & -188.4 & -180.7 \\
& b & -29.8 & -22.4 \\
$\mathrm{CH}_{3} \mathrm{OCH}_{3}$ & a & -192.1 & -184.3 \\
& b & -30.7 & -21.9 \\
$\mathrm{CH}_{3} \mathrm{COCH}_{3}$ & a & -196.7 & -188.9 \\
& b & -30.1 & -21.4 \\
\hline
\end{tabular}

Source: References 7 and $13-15$. and $\left(\mathrm{CH}_{3} \mathrm{COCH}_{3}\right) \mathrm{H}^{+}$, which were converted fully into the corresponding dimers by the collision-stabilized association reactions [22-24]

$$
\mathrm{AH}^{+}+\mathrm{A}+\mathrm{He} \rightarrow \mathrm{A}_{2} \mathrm{H}^{+}+\mathrm{He}
$$

where $\mathrm{A} \equiv \mathrm{CH}_{3} \mathrm{CN}, \mathrm{CH}_{3} \mathrm{OCH}_{3}$, and $\mathrm{CH}_{3} \mathrm{COCH}_{3}$ respectively. The neutrals acetonitrile, dimethyl ether, or acetone were introduced into the flow tube through an inlet port that follows the Venturi inlet [4] very closely in space. The other pure or mixed proton-bound dimers were produced in a similar fashion. Optimal flow rates were 1.5 to $2 \mathrm{~cm}^{3} / \mathrm{min}$ for reactant $\mathrm{A}$ and $7 \mathrm{~L} / \mathrm{min}$ for He. The helium pressures in the tube were 0.331 to 0.371 torr and the temperature was $298 \mathrm{~K}$.

Second-order rate coefficients were obtained by monitoring the intensity of the primary $\mathrm{A}_{2} \mathrm{H}^{+}$ion decay as a function of the neutral reactant gas $B$ concentration introduced downstream from the inlet of A $\left(\mathrm{CH}_{3} \mathrm{CN}, \mathrm{CH}_{3} \mathrm{OCH}_{3}\right.$, or $\mathrm{CH}_{3} \mathrm{COCH}_{3}$, respectively). Product ion distributions were obtained by plotting the percentage of each product ion as a function of the gas $B$ flow rate and extrapolating the resulting curves to zero flow rate. Product ion distributions were corrected via the measured mass discrimination factors of the detector quadrupole mass filter.

\section{Results and Discussion}

We have reacted the three protonated dimers $\left(\mathrm{CH}_{3} \mathrm{CN}\right)_{2} \mathrm{H}^{+},\left(\mathrm{CH}_{3} \mathrm{COCH}_{3}\right)_{2} \mathrm{H}^{+}$, and $\left(\mathrm{CH}_{3} \mathrm{OCH}_{3}\right)_{2} \mathrm{H}^{+}$ with a series of base molecules $\mathrm{B}$ spanning the $\mathrm{PA}$ range from 181.9 (methanol) to $232.3 \mathrm{kcal} / \mathrm{mol}$ (triethyl amine). The following primary reactions were observed $\left(\mathrm{A} \equiv \mathrm{CH}_{3} \mathrm{CN}, \mathrm{CH}_{3} \mathrm{OCH}_{3}\right.$ or $\mathrm{CH}_{3} \mathrm{COCH}_{3}$ ):

$$
\begin{aligned}
\text { Association: } & \mathrm{A}_{2} \mathrm{H}^{+}+\mathrm{B} \stackrel{\mathrm{He}}{\rightarrow} \mathrm{A}_{2} \mathrm{BH}^{+} \\
\text {Switching: } & \mathrm{A}_{2} \mathrm{H}^{+}+\mathrm{B} \rightarrow \mathrm{ABH}^{+}+\mathrm{A} \\
\text { Proton transler: } & \mathrm{A}_{2} \mathrm{H}^{+}+\mathrm{B} \rightarrow \mathrm{BH}^{+}+2 \mathrm{~A}
\end{aligned}
$$

Reaction (4), [proton transfer (PT)] was observed only for base molecules $B$ having very high proton affinities. This is understandable upon inspection of Table 1 because reaction (5),

$$
\mathrm{A}_{2} \mathrm{H}^{+} \rightarrow \mathrm{H}^{+}+2 \mathrm{~A}
$$

has endothermicities, $\Delta H^{\circ}$ of $218.2,222.8$, and 226.8 $\mathrm{kcal} / \mathrm{mol}$ and $\Delta G^{\circ}$ values of 203.1, 206.2, and 210.3 $\mathrm{kcal} / \mathrm{mol}$ for acetonitrile, dimethyl ether, and acetone, respectively. Reaction (4) is probably not a single-step process. Evaporation of ligand A may follow the ligand switching (SW) reaction (3) [4]. Reaction (2) [collisionally stabilized association (AS)] was observed for base molecules that have low and high proton affinities and an association-insertion mechanism is proposed in the upcoming discussion. 


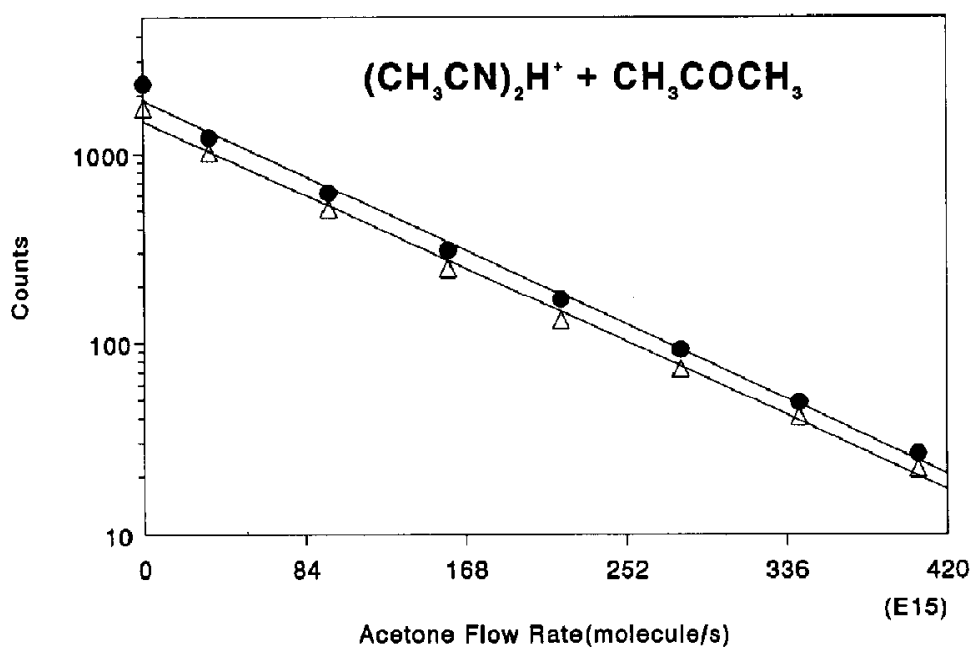

Figure 1. Semilogarithmic plot of the decay of the primary ion as a function of the neutral flow rate for the reaction of the protonated dimer of acetonitrile with neutral acetone (the results of two experiments).

\section{Rate Constants}

Figure 1 reproduces the data for two experiments for the reaction

$$
\left(\mathrm{CH}_{3} \mathrm{CN}\right)_{2} \mathrm{H}^{+}+\mathrm{CH}_{3} \mathrm{COCH}_{3} \rightarrow \text { products }
$$

The pseudo first-order-rate constant is derived as usual from the linear slope of the semilogarithmic plot, and that leads to the second-order rate constant from the known neutral concentration. Results for the reactions of the three dimers are summarized in Tables 2, 3, and 4 , respectively. The largest estimated error limits for the rate constants are $\pm 30 \%$. Some reactions were very slow and only an estimated upper limit of the rate constant is given. The experimental rate constants $k_{\exp }$ are compared with calculated collision rate constants $k_{c}$. The latter were calculated by using the parametrized expression of $\mathrm{Su}$ and Chesnavich [25] because this approach is recommended above $100 \mathrm{~K}$ [26]. The calculated values are included in Tables 2 to 4 . Thermochemical information for the reactions observed is included in Tables 2 to 4 , where available. For example, the thermochemistry of the methanol-acetonitrile and methanol-dimethyl ether clustering reactions has been reported $([8,27]$ and Daly, G. M., Gao, J., El-Shall, M. S., submitted for publication in J. Am. Chem. Soc.) and unpublished data are available (Meot-Ner (Mautner), M.r private communication) for ammonia-acetone reactions. Other thermochemical information for mixed dimers is available trom correlations between bond dissociation energies $\Delta H_{D}^{\circ}$ and the difference $\Delta P A$ between the proton affinities of the proton donor and the proton acceptor [28]. Thermochemical information

Table 2. Rate constants and branching ratios for reactions of $\left(\mathrm{CH}_{3} \mathrm{CN}\right)_{2} \mathrm{H}^{\prime}$ with a series of base molecules

\begin{tabular}{|c|c|c|c|c|c|c|c|c|c|c|c|c|}
\hline \multirow{2}{*}{$\begin{array}{c}\text { B } \\
\text { (neutral) }\end{array}$} & \multirow{2}{*}{$\begin{array}{c}\mathrm{PA}^{\mathrm{a}} \\
\text { (kcal// } \\
\mathrm{mol})\end{array}$} & \multirow{2}{*}{$\begin{array}{c}k_{\text {exp }} \\
\left(10^{-9} \mathrm{~cm}^{3} /\right. \\
\text { molecule } \cdot \mathrm{s})\end{array}$} & \multirow{2}{*}{$\begin{array}{c}k_{\mathrm{c}} \\
\left(10^{-9} \mathrm{~cm}^{3} /\right. \\
\text { molecule } \cdot \mathrm{s})\end{array}$} & \multicolumn{3}{|c|}{$\begin{array}{c}\text { Product ion } \\
\text { distribution }(\%)\end{array}$} & \multicolumn{3}{|c|}{$\Delta H^{\circ}(\mathrm{kcal} / \mathrm{mol})$} & \multicolumn{3}{|c|}{$\Delta G^{\circ}(\mathrm{kcal} / \mathrm{mol})$} \\
\hline & & & & AS & sw & $\overline{\mathbf{P T}}$ & AS & sw & PT & AS & sw & PT \\
\hline 1. $\mathrm{CH}_{3} \mathrm{OH}$ & 181.9 & 0.24 & 1.91 & 99.3 & 4.7 & - - & $-21^{b}$ & $+1^{b}$ & +36.3 & $-14^{b}$ & $+2^{b}$ & +29 \\
\hline 2. $\mathrm{CH}_{3} \mathrm{CHO}$ & 186.6 & 0.19 & 2.51 & 2.4 & 97.6 & - & & & +31.6 & & & +24.5 \\
\hline 4. $\mathrm{CH}_{3} \mathrm{OCH}_{3}$ & 192.1 & 0.36 & 1.53 & - & 100 & - & & & +26.1 & & & +18.8 \\
\hline 5. $\mathrm{CH}_{3} \mathrm{COCH}_{3}$ & 196.7 & 1.27 & 2.53 & - & 100 & - & & & +21.5 & & & +14.2 \\
\hline 6. $\mathrm{CH}_{3} \mathrm{COOC}_{2} \mathrm{H}_{5}$ & 200.7 & 1.14 & 1.15 & - & 100 & - & & & +17.5 & & & +10.2 \\
\hline 7. $\mathrm{NH}_{3}$ & 204.0 & 0.40 & 2.10 & 70 & 30 & - & & & +14.2 & & & +7.5 \\
\hline 8. $\mathrm{CH}_{3} \mathrm{OCH}_{2} \mathrm{CH}_{2} \mathrm{OCH}_{3}$ & 204.9 & 0.70 & - & - & 100 & - & & & +13.3 & & & +7.3 \\
\hline 9. $\mathrm{CH}_{3} \mathrm{NH}_{2}$ & 214.1 & 0.75 & 1.70 & 62.3 & 37.3 & 0.4 & $-37.6^{c}$ & $-20.4^{\mathrm{d}}$ & +4.1 & & $-19.4^{d}$ & -2.6 \\
\hline 10. $\mathrm{Me}_{2} \mathrm{NH}$ & 220.6 & 0.83 & 1.43 & 42 & 51 & 7 & & & -2.4 & & & -9.7 \\
\hline 11. $\mathrm{Me}_{3} \mathrm{~N}$ & 225.1 & 0.78 & 1.25 & - & 93.3 & 6.7 & & & -6.9 & & & -14.2 \\
\hline 12. $\mathrm{Et}_{3} \mathrm{~N}$ & 232.3 & 0.91 & 1.35 & - & 76 & 24 & & & -14.1 & & & -21.4 \\
\hline
\end{tabular}

a PA values are from ref 15 .

Based on experimental values from Daly, G. M., Gao, J., and El-Shall, M. S. (submitted for publication in $J$. Am. Chem. Soc.) and ref 27

crom relations between enthalpies of solvation [29].

dExperimental values from ref $\mathbf{2 8}$. 
Table 3. Rate constants and branching ratios for reactions of $\left(\mathrm{CH}_{3} \mathrm{OCH}_{3}\right)_{2} \mathrm{H}^{+}$with a series of base molecules

\begin{tabular}{|c|c|c|c|c|c|c|c|c|c|c|c|c|}
\hline \multirow{2}{*}{$\begin{array}{c}\text { B } \\
\text { (neutral) }\end{array}$} & \multirow{2}{*}{$\begin{array}{c}\mathrm{PA}^{\mathrm{a}} \\
(\mathrm{kcal} / \\
\mathrm{mol}\rangle\end{array}$} & \multirow{2}{*}{$\begin{array}{c}k_{\exp } \\
\left(10^{-9} \mathrm{~cm}^{3} /\right. \\
\text { molecule } \cdot \mathrm{s})\end{array}$} & \multirow{2}{*}{$\begin{array}{c}k_{\mathrm{C}} \\
\left(10^{-9} \mathrm{~cm}^{3} /\right. \\
\text { molecule } \cdot \mathrm{s})\end{array}$} & \multicolumn{3}{|c|}{$\begin{array}{l}\text { Product ion } \\
\text { distribution (\%) }\end{array}$} & \multicolumn{3}{|c|}{$\Delta H^{\circ}(\mathrm{kcal} / \mathrm{mol})$} & \multicolumn{3}{|c|}{$\Delta G^{\circ}(\mathrm{kcal} / \mathrm{mol})$} \\
\hline & & & & AS & SW & PT & AS & SW & PT & AS & SW & PT \\
\hline 1. $\mathrm{CH}_{3} \mathrm{OH}$ & 181.9 & $\leq 0.03$ & 1.88 & 84 & 16 & - & $-18.1^{b}$ & $+4.4^{b}$ & +40.9 & $-9.0^{b}$ & $+3.7^{b}$ & +32.1 \\
\hline 2. $\mathrm{CH}_{3} \mathrm{CHO}$ & 186.6 & $\leq 0.03$ & 2.47 & - & 100 & - & & & +36.2 & & & +27.6 \\
\hline 3. $\mathrm{CH}_{3} \mathrm{CN}$ & 188.4 & 0.57 & 3.41 & - & 100 & - & & & +34.4 & & & +25.5 \\
\hline 5. $\mathrm{CH}_{3} \mathrm{COCH}_{3}$ & 196.7 & 1.19 & 2.47 & - & 100 & - & & & +26.1 & & & +17.3 \\
\hline 6. $\mathrm{CH}_{3} \mathrm{COOC}_{2} \mathrm{H}_{5}$ & 200.7 & 1.17 & 1.11 & - & 100 & - & & & +22.1 & & & +13.3 \\
\hline 7. $\mathrm{NH}_{3}$ & 204.0 & 0.14 & 2.09 & - & 99.9 & 0.1 & $-24.7^{c}$ & $-6.8^{d}$ & +18.8 & & & +10.6 \\
\hline 8. $\mathrm{CH}_{3} \mathrm{OCH}_{2} \mathrm{CH}_{2} \mathrm{OCH}_{3}$ & 204.9 & 0.55 & - & - & 100 & - & & & +17.9 & & & +10.4 \\
\hline 9. $\mathrm{CH}_{3} \mathrm{NH}_{2}$ & 214.1 & 0.30 & 1.67 & - & 98 & 2 & $-27.9^{c}$ & $-12.8^{e}$ & +8.7 & & $-12.3^{\mathrm{e}}$ & +0.5 \\
\hline 10. $\mathrm{Me}_{2} \mathrm{NH}$ & 220.6 & 0.18 & 1.40 & - & 94 & 6 & $-34.7^{c}$ & $-19.5^{d}$ & +2.2 & & & -6.6 \\
\hline 11. $\mathrm{Me}_{3} \mathrm{~N}$ & 225.1 & 0.033 & 1.23 & - & 42 & 58 & $-37.5^{c}$ & $-23.0^{d}$ & -2.3 & & & -11.1 \\
\hline 12. $\mathrm{Et}_{3} \mathbf{N}$ & 232.3 & $\leq 0.03$ & 1.31 & - & 93.4 & 6.6 & $-41.9^{\mathrm{c}}$ & $-28.6^{d}$ & -9.5 & & & -18.3 \\
\hline
\end{tabular}

a pA values are from ref 15

Experimental fesults from ref 8.

"From relations between enthalpies of solvation [29].

dFrom linear correlations between bond dissociation energies and differences between proton affinities [28]

Experimental values from ref 28 .

about mixed trimers is available from estimates for relations between enthalpies of ion solvation [29].

Most of the reaction rates are much slower than gas kinetic. This is in marked contrast to the behavior of the protonated trimer of methanol [4], whose reaction rates were found to be near collision rates for exothermic reactions. The experimental rate constants are compared with the calculated collision rates for the protonated dimers of acetone and dimethyl ether in Figures 2 and 3 , respectively. Whereas for $\left(\mathrm{CH}_{3} \mathrm{COCH}_{3}\right)_{2} \mathrm{H}^{+}$the experimental rate constants approach collision rates for base molecules of high proton affinities (Figure 2), those for $\left(\mathrm{CH}_{3} \mathrm{OCH}_{3}\right)_{2} \mathrm{H}^{+}$go through a maximum and then decline at higher PAs (Figure 3). The behavior of $\left(\mathrm{CH}_{3} \mathrm{CN}\right)_{2} \mathrm{H}^{+}$is intermediate. The conclusion at this point is that the reactivity of the dimers is not governed solely by thermochemistry. In other words, these reactions are not intrinsically fast reactions, characterized by a single-intermediate oneminimum potential energy surface. It is rather safe to assume that they are characterized by double-well surfaces with intermediate barriers [30-33]. As noted earlier, $\left(\mathrm{CH}_{3} \mathrm{CN}\right)_{2} \mathrm{H}^{+}, \quad\left(\mathrm{CH}_{3} \mathrm{COCH}_{3}\right)_{2} \mathrm{H}^{+}$, and $\left(\mathrm{CH}_{3} \mathrm{OCH}_{3}\right)_{2} \mathrm{H}^{+}$have no hydrogen bonding protons

Table 4. Rate constants and branching ratios for reactions of $\left(\mathrm{CH}_{3} \mathrm{COCH}_{3}\right)_{2} \mathrm{H}^{+}$with a series of base molecules

\begin{tabular}{|c|c|c|c|c|c|c|c|c|c|c|c|c|}
\hline \multirow{2}{*}{$\begin{array}{c}\text { B } \\
\text { (neutral) }\end{array}$} & \multirow{2}{*}{$\begin{array}{c}\mathrm{PA}^{\mathrm{a}} \\
(\mathrm{kcal} / \\
\mathrm{mol})\end{array}$} & \multirow{2}{*}{$\begin{array}{c}k_{\exp } \\
\left(10^{-9} \mathrm{~cm}^{3} /\right. \\
\text { molecule } \cdot \mathrm{s})\end{array}$} & \multirow{2}{*}{$\begin{array}{c}k_{\mathrm{c}} \\
\left(10^{-9} \mathrm{~cm}^{3} /\right. \\
\text { molecule } \cdot \mathrm{s})\end{array}$} & \multicolumn{3}{|c|}{$\begin{array}{c}\text { Product ion } \\
\text { distribution (\%) }\end{array}$} & \multicolumn{3}{|c|}{$\Delta H^{\circ}(\mathrm{kcal} / \mathrm{mol})$} & \multicolumn{3}{|c|}{$\Delta G^{\circ}(\mathrm{kcal} / \mathrm{mol})$} \\
\hline & & & & $\overline{A S}$ & SW & PT & AS & SW & PT & AS & SW & PT \\
\hline 1. $\mathrm{CH}_{3} \mathrm{OH}$ & 181.9 & $\leq 0.03$ & 1.83 & 100 & - & - & & & +44.9 & & & +36.2 \\
\hline 2. $\mathrm{CH}_{3} \mathrm{CHO}$ & 186.6 & $\leq 0.03$ & 2.38 & - & 100 & - & & & +40.2 & & & +31.7 \\
\hline 3. $\mathrm{CH}_{3} \mathrm{CN}$ & 188.4 & $\leq 003$ & 3.30 & - & 100 & - & & & +38.4 & & & +29.6 \\
\hline 4. $\mathrm{CH}_{3} \mathrm{OCH}_{3}$ & 192.1 & $\leq 0.03$ & 1.45 & - & 100 & - & & & +34.7 & & & +26.0 \\
\hline 6. $\mathrm{CH}_{3} \mathrm{COOC}_{2} \mathrm{H}_{3}$ & 200.7 & 0.74 & 1.06 & - & 100 & - & & & +26.1 & & & +17.4 \\
\hline 7. $\mathrm{NH}_{3}$ & 204.0 & 0.22 & 2.06 & 60 & 40 & - & $-25.8^{b}$ & $-5.6^{b}$ & +22.8 & $-18.9^{b}$ & $-6.0^{\mathrm{b}}$ & +14.7 \\
\hline 8. $\mathrm{CH}_{3} \mathrm{OCH}_{2} \mathrm{CH}_{2} \mathrm{OCH}_{3}$ & 204.9 & 0.58 & - & - & 100 & - & & & +21.9 & & & +14.5 \\
\hline 9. $\mathrm{CH}_{3} \mathrm{NH}_{2}$ & 214.1 & 1.09 & 1.63 & 54 & 46 & $<1$ & $-28.1^{c}$ & $-11.3^{d}$ & +12.7 & & $-12.5^{d}$ & +4.6 \\
\hline 10. $\mathrm{Me}_{2} \mathrm{NH}$ & 220.6 & 0.96 & 1.35 & 51 & 49 & $<1$ & $-32.6^{r}$ & $-16.6^{e}$ & +6.2 & & & -2.5 \\
\hline 11. $\mathrm{Me}_{2} \mathrm{~N}$ & 225.1 & 0.97 & 1.18 & - & 99.6 & $\leq 0.4$ & $-35.4^{c}$ & $-20.1^{e}$ & +1.7 & & & -7.0 \\
\hline 12. $\mathrm{Et}_{3} \mathrm{~N}$ & 232.3 & 1.03 & 1.24 & - & 61 & 39 & $-39.7^{c}$ & $-25.6^{\mathrm{e}}$ & -5.5 & & & -14.2 \\
\hline
\end{tabular}

a PA values are from ref 15.

Experimental results from M. Meot-Ner (Mautner) (private communication).

'From relations between enthalpies of solvation [29].

Experimental results from ref $\mathbf{2 8}$.

- From linear correlations between band dissociation energies and diferences between proton affinities [28]. 


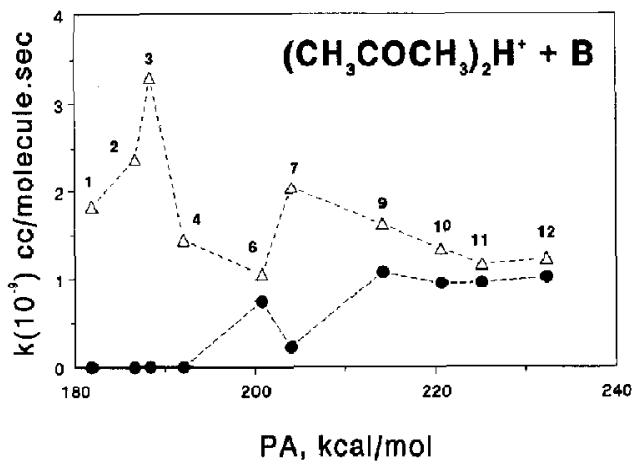

Figure 2. Reaction rate constants for reactions of the protonated dimer of acetone with a series of base molecules $\mathbf{B}$, as a function of their proton affinity. - experimental; $\Delta$ : calculated collision rate. The numbering of the base molecules corresponds to Table 4.

in the periphery and there is a steric hindrance to trimer formation. We suggest that the central barrier in the series of reactions $\mathrm{A}_{2} \mathrm{H}^{+}+\mathrm{B}$ studied here is due to a similar steric hindrance against the approach of $B$ to the central $\mathrm{O}-\mathrm{H}-\mathrm{O}$ or $\mathrm{N}-\mathrm{H}-\mathrm{N}$ bridge. It is interesting to note, however, that there are some bulky base molecules such as $\mathrm{CH}_{3} \mathrm{COOC}_{2} \mathrm{H}_{5}$, that have relatively large rate constants. We will return to this question later.

\section{Product Ion Distributions; Ligand Insertion}

Product ion distributions (or branching ratios) are included in Tables 2 to 4 . We estimate them to be correct to within $\pm 2 \%$. By plotting the percentage of each product ion as a function of the gas B flow rate, it is relatively easy to distinguish between primary and secondary products. Figure 4 demonstrates this for the

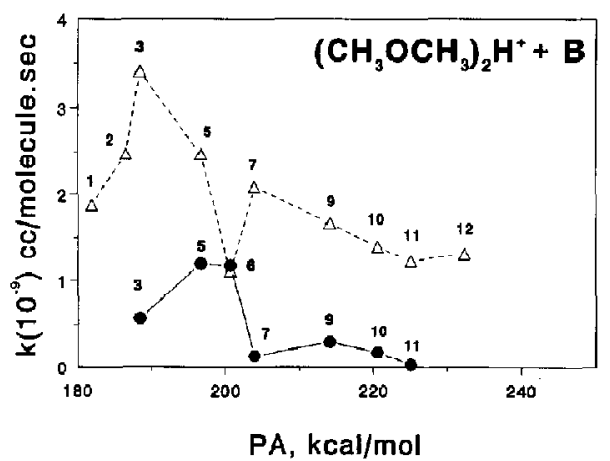

Figure 3. Reaction rate constants for reactions of the protonated dimer of dimethyl ether with a series of base molecules B, as a function of their proton affinity. $\bullet$ : experimental; $\Delta$ : calculated collision rate. The numbering corresponds to Table 3 .

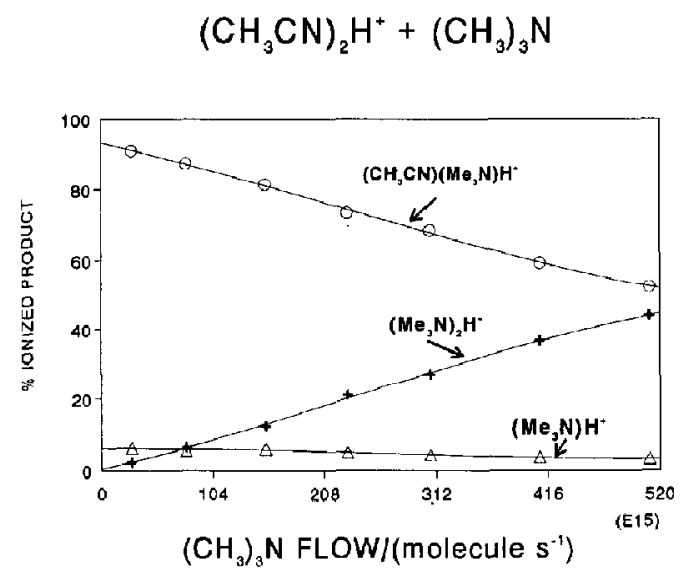

Figure 4. Product ion distribution as a function of the neutral flow rate for the reaction of the protonated dimer of acetonitrile with trimethyl amine.

set of reactions

$$
\begin{aligned}
& \left(\mathrm{CH}_{3} \mathrm{CN}\right)_{2} \mathrm{H}^{+}+\left(\mathrm{CH}_{3}\right)_{3} \mathrm{~N} \\
& \stackrel{\mathrm{PT}}{\longrightarrow}\left(\mathrm{CH}_{3}\right)_{3} \mathrm{NH}^{+}+2 \mathrm{CH}_{3} \mathrm{CN} \\
& \stackrel{\mathrm{SW}}{\longrightarrow}\left(\mathrm{CH}_{3} \mathrm{CN}\right)\left(\left(\mathrm{CH}_{3}\right)_{3} \mathrm{~N}^{+} \mathrm{H}^{+}\right. \\
& \quad\left(\left(\mathrm{CH}_{3}\right)_{3} \mathrm{~N}, \mathrm{SW}\right.
\end{aligned}
$$

Material balance demonstrates that the majority of the protonated dimer of trimethyl amine is formed by two consecutive switching reactions. The appearance of the secondary product is quite distinct in the semilogarithmic plot of ion counts versus flow rate (Figure 5). In this case the major primary product ion is quite reactive; in other cases this is not so. Of special interest is

$$
\left(\mathrm{CH}_{3} \mathrm{CN}\right)_{2} \mathrm{H}^{+}+\left(\mathrm{CH}_{3}\right)_{3} \mathrm{~N}
$$

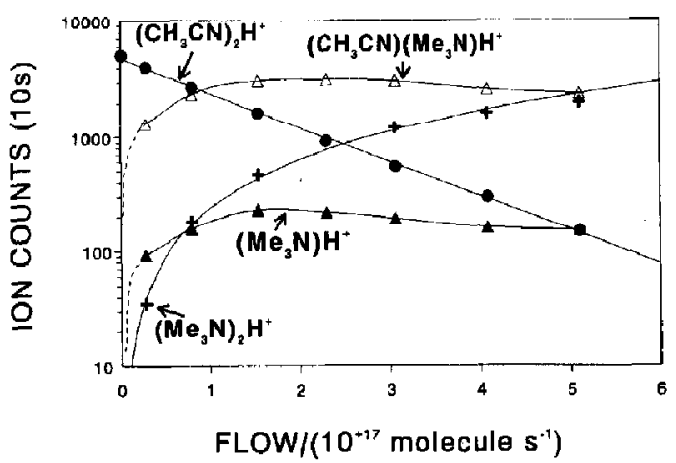

Figure 5. Variation with $\left(\mathrm{CH}_{3}\right)_{3} \mathrm{~N}$ flow of the primary and product ion count rates for the reaction of $\left(\mathrm{CH}_{3} \mathrm{CN}_{2} \mathrm{H}^{+}\right.$with $\left(\mathrm{CH}_{3}\right)_{3} \mathrm{~N}$. 


$$
\left(\mathrm{CH}_{3} \mathrm{COCH}_{3}\right)_{2} \mathrm{H}^{+}+\mathrm{NH}_{3}
$$

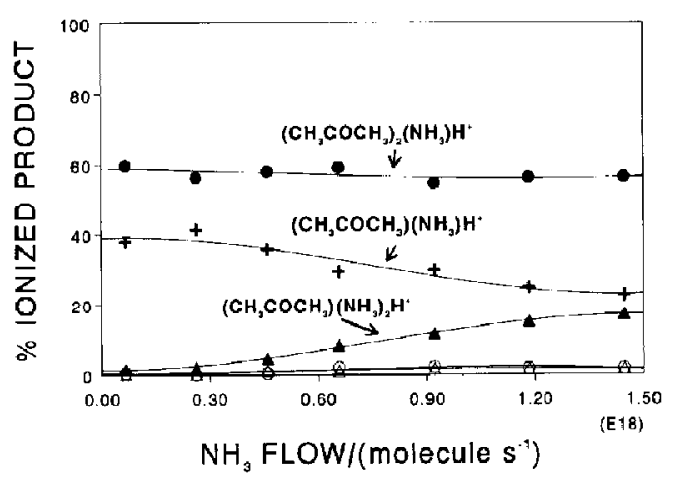

Figure 6. Product ion distribution as a function of the neutral flow rate for the reaction of the protonated dimer of acetone with ammonia. $\Delta:\left(\mathrm{NH}_{3}\right)_{2} \mathrm{H}^{+} ; \circ:\left(\mathrm{NH}_{3}\right)_{3} \mathrm{H}^{+}$.

the $\left(\mathrm{CH}_{3} \mathrm{COCH}_{3}\right)_{2} \mathrm{H}^{+}-\mathrm{NH}_{3}$ reaction system (Figure 6)

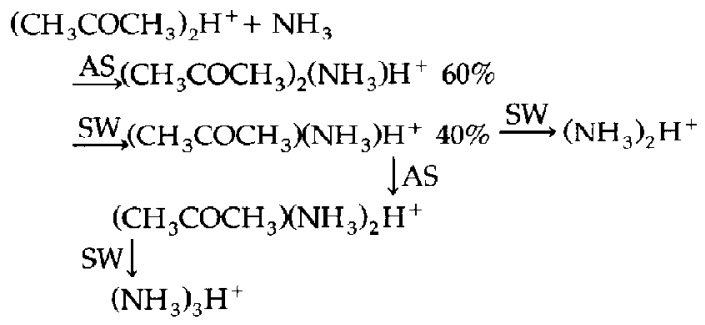

for which the association product $\left(\mathrm{CH}_{3} \mathrm{COCH}_{3}\right)_{2}$ $\left(\mathrm{NH}_{3}\right) \mathrm{H}^{+}$is quite unreactive. The association channel is observed for molecules of low proton affinity, for example, methanol (Figure 7). It disappears for molecules of intermediate proton affinity, reappears for molecules of relatively high PA, and disappears again for molecules of very high PA, such as triethyl amine (Figure 8). A plot of the branching ratios for association, switching, and proton transfer as a function of $\mathrm{PA}$ of $\mathrm{B}$ is given in Figure 9 for reactions of $\left(\mathrm{CH}_{3} \mathrm{COCH}_{3}\right)_{2} \mathrm{H}^{+}$with a series of bases. Similar results were obtained for $\left(\mathrm{CH}_{3} \mathrm{CN}\right)_{2} \mathrm{H}^{+}$, but not for $\left(\mathrm{CH}_{3} \mathrm{OCH}_{3}\right)_{2} \mathrm{H}^{+}$. Inspection of the acetone and acetonitrile data shows that association reappears for ammonia (A), methyl amine (M), and dimethyl amine (D) (Figure 9); in other words, for nitrogen bases that have at least one $\mathrm{N}-\mathrm{H}$ bond. This led to two experiments with base molecules that have similar or slightly higher PAs than that of ammonia- $\mathrm{CH}_{3} \mathrm{OCH}_{2} \mathrm{CH}_{2} \mathrm{OCH}_{3}$ $(\mathrm{PA}=204.9 \mathrm{kcal} / \mathrm{mol})$ and $\left(i-\mathrm{C}_{3} \mathrm{H}_{7}\right)_{2} \mathrm{O}(\mathrm{PA}=206.0$ $\mathrm{kcal} / \mathrm{mol}$ )-neither of which leads to association reactions with the proton-bound dimers (Figure 9). Clearly, the association reaction occurring with $A, M$, and $D$ is chemical in nature and not necessarily related to the PA. Another base molecule, $\mathrm{HCONH}_{2}$ that has a PA that is 5 to $6 \mathrm{kcal} / \mathrm{mol}$ smaller than that of ammonia,

$$
\left(\mathrm{CH}_{3} \mathrm{CN}\right)_{2} \mathrm{H}^{+}+\mathrm{CH}_{3} \mathrm{OH}
$$

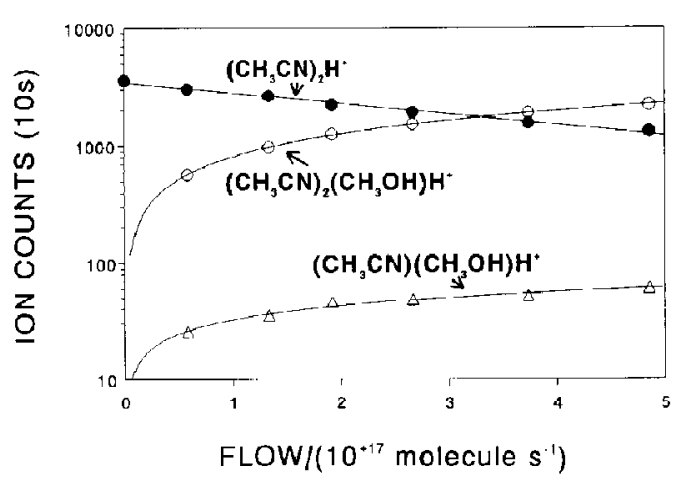

Figure 7. Variation with $\mathrm{CH}_{3} \mathrm{OH}$ flow of the primary and product ion count rates for the reaction of $\left(\mathrm{CH}_{3} \mathrm{CN}\right)_{2} \mathrm{H}^{+}$with $\mathrm{CH}_{3} \mathrm{OH}$.

but possesses $\mathrm{N}-\mathrm{H}$ bonds, demonstrated a fraction of at least $17 \%$ of association products. The results demonstrate that reactions with $\mathrm{A}, \mathrm{M}$, and $\mathrm{D}$ lead to insertion in which $\mathrm{NH}_{4}^{+}$, instead of the proton, is the central ion with two A molecules symmetrically bound to it. This insertion is a two-step process: (1) Attack on the proton of the $\mathrm{O}-\mathrm{H}-\mathrm{O}$ or $\mathrm{N}-\mathrm{H}-\mathrm{N}$ bridge by the lone pair of nitrogen electrons and (2) rearrangement to a V-shaped trimer structure (Scheme I). The rearrangement step is probably responsible for a central barrier in the potential surface and the relatively low reactivities. Ions that have $\mathrm{NH}_{4}^{+}$in the center and either $\mathrm{CH}_{3} \mathrm{CN}$ or $\mathrm{CH}_{3} \mathrm{COCH}_{3}$ in the periphery are well known from multiphoton ionization of neutral mixed clusters [34, 35]. Upon unimolecular fragmentation, ions $\left(\mathrm{NH}_{3}\right) \mathrm{A}_{2} \mathrm{H}^{+}\left(\mathrm{A} \equiv \mathrm{CH}_{3} \mathrm{CN}\right.$ or $\left.\mathrm{CH}_{3} \mathrm{COCH}_{3}\right)$ lose the acetonitrile or acetone, but not the ammonia

$$
\left(\mathrm{CH}_{3} \mathrm{CN}\right)_{2} \mathrm{H}^{+}+\mathrm{Et}_{3} \mathrm{~N}
$$

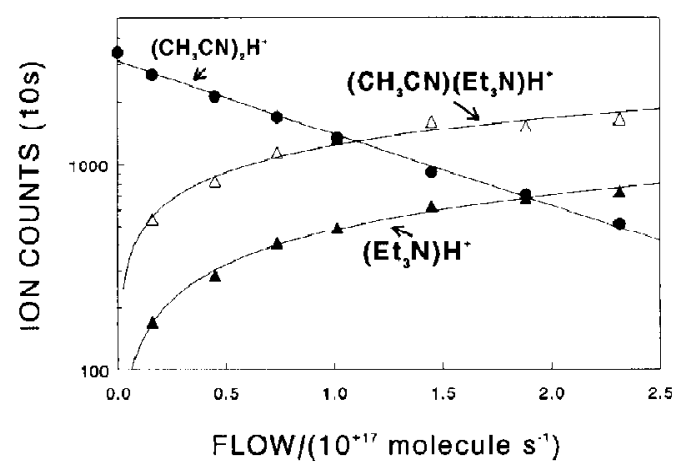

Figure 8. Variation with $\left(\mathrm{C}_{2} \mathrm{H}_{5}\right)_{3} \mathrm{~N}$ flow of the primary and product ion count rates for the reaction of $\left(\mathrm{CH}_{3} \mathrm{CN}_{2} \mathrm{H}^{\mathrm{H}}\right.$ with $\left(\mathrm{C}_{2} \mathrm{H}_{5}\right)_{3} \mathrm{~N}$. 


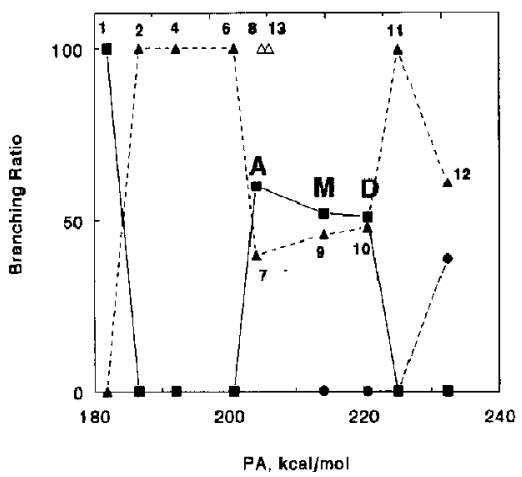

Figure 9. Branching ratio of the product ions as a function of proton affinity of $\mathrm{B}$ in the general reactions: $\left(\mathrm{CH}_{3} \mathrm{COCH}_{3}\right)_{2} \mathrm{H}^{+}+$ $\mathrm{B} \rightarrow$ products. The products are $\mathbf{v}$ : association; $\Delta, \Delta$ : switching; - proton transfer. The numbering of the base molecules corresponds to Table 4. A: ammonia; M: methyl amine; D: dimethyl amine, $\Delta$ signifies bases having no hydrogen bonding protons; $\mathrm{CH}_{3} \mathrm{OCH}_{2} \mathrm{CH}_{2} \mathrm{OCH}_{3}(8)$ and $\left(i-\mathrm{C}_{3} \mathrm{H}_{7}\right)_{2} \mathrm{O}(13)$.<smiles></smiles>

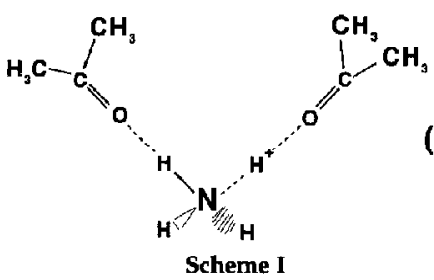<smiles>CC#[N+][C@H](OC)[C@H](C)N=CC</smiles><smiles></smiles>

(ii)

[34, 35]. Similarly, collision-induced dissociation (CID) of adduct ions $\left(\mathrm{Et}_{2} \mathrm{CO}\right)_{2}\left(\mathrm{NH}_{3}\right) \mathrm{H}^{+}$and $\left(\mathrm{ET}_{2} \mathrm{CO}\right)_{2}\left(\mathrm{CH}_{3} \mathrm{NH}_{2}\right) \mathrm{H}^{+}$, formed in the ammonia or methyl amine chemical ionization of the ketone [36], leads to loss of the ketone under both low and high energy CID. A proton-bound cluster ion in which $\mathrm{NH}_{4}^{+}$ is the central entity is consistent with these results. These literature data [34-36] lend further support to the insertion mechanism proposed in Scheme I. Tri-<smiles>O=COCCO</smiles>

Sicheme III

Table 5. Product ion distributions for reactions of dimers with ammonia ${ }^{a}$

\begin{tabular}{|c|c|c|c|c|c|c|c|c|c|}
\hline \multirow[b]{2}{*}{ Dimer } & \multicolumn{3}{|c|}{ Product ion distribution (\%) } & \multicolumn{3}{|c|}{$\Delta H^{\circ}(\mathrm{kcal} / \mathrm{mol})$} & \multicolumn{3}{|c|}{$\Delta G^{\circ}(\mathrm{kcal} / \mathrm{mol})$} \\
\hline & AS & SW & PT & AS & SW & PT & AS & SW & PT \\
\hline$(\mathrm{HCOOH})_{2} \mathrm{H}^{+}$ & & 100 & & & & & & & \\
\hline$\left(\mathrm{CH}_{3} \mathrm{CHO}\right)_{2} \mathrm{H}^{+}$ & 71 & 29 & - & & & & & & \\
\hline$\left(\mathrm{CH}_{3} \mathrm{CN}\right)_{2} \mathrm{H}^{+}$(Table 2) & 70 & 30 & - & & & +14.2 & & & +7.5 \\
\hline$\left\{\mathrm{CH}_{3} \mathrm{OCH}_{3}\right\}_{2} \mathrm{H}^{+}$(Table 3) & - & 100 & - & -24.7 & -6.8 & +18.8 & & & +10.6 \\
\hline$\left(\mathrm{CH}_{3} \mathrm{COCH}_{3}\right)_{2} \mathrm{H}^{+}$(Table 4) & 60 & 40 & - & -25.8 & -5.5 & +22.8 & -18.9 & -6.0 & +14.7 \\
\hline$\left(\mathrm{CH}_{3} \mathrm{COOC}_{2} \mathrm{H}_{6}\right)_{2} \mathrm{H}^{+}$ & 69 & 31 & - & $-20^{b}$ & $-0.8^{c . d}$ & $+26.7^{c}$ & & & $+19.7^{c}$ \\
\hline$\left(\mathrm{C}_{2} \mathrm{H}_{5} \mathrm{OC}_{2} \mathrm{H}_{5}\right)_{2} \mathrm{H}^{+}$ & - & 100 & - & & & & & & \\
\hline$\left(\mathrm{C}_{4} \mathrm{H}_{8} \mathrm{O}\right)_{2} \mathrm{H}^{+}$(tetrahydrofuran) & 64 & 36 & - & & & & & & \\
\hline$\left(\mathrm{CH}_{3} \mathrm{OCH}_{2} \mathrm{CH}_{2} \mathrm{OCH}_{3}\right)_{2} \mathrm{H}^{+}$ & 84 & 16 & - & & & & & & \\
\hline$\left(\mathrm{CH}_{3} \mathrm{CN}\right)\left(\mathrm{CH}_{3} \mathrm{COCH}_{3}\right) \mathrm{H}^{+}$ & 26 & $74^{\circ}$ & - & & & & & & \\
\hline$\left(\mathrm{CH}_{3} \mathrm{CN}\right)\left(\mathrm{CH}_{3} \mathrm{OCH}_{3}\right) \mathrm{H}^{+}$ & - & 100 & - & & & & & & \\
\hline$\left(\mathrm{CH}_{3} \mathrm{COCH}_{3} \mathrm{KCH}_{3} \mathrm{OCH}_{3}\right) \mathrm{H}^{+}$ & - & $95.4^{\dagger}$ & 4.6 & & & & & & \\
\hline$\left(\mathrm{CH}_{3} \mathrm{OCH}_{2} \mathrm{CH}_{2} \mathrm{OCH}_{3}\right)\left(\mathrm{CH}_{3} \mathrm{OH}\right) \mathrm{H}^{+}$ & - & $99.5^{9}$ & 0.5 & & & & & & \\
\hline
\end{tabular}

'Branching ratios were measured at a minimum flow rate of $0.11 \mathrm{~cm}^{3} / \mathrm{min}$ ammonia.

${ }^{b}$ Relations between enthalpies of solvation.

'Keesee, R. G.; Castleman, A. W., Jr. J. Phys. Chem. Ref. Data 1986, 15, 1011-1071.

dinear correlations [28].

${ }^{\circ} 30 \%\left(\mathrm{CH}_{3} \mathrm{COCH}_{3}\right)\left(\mathrm{NH}_{3}\right) \mathrm{H}^{+}$and $40 \%\left(\mathrm{CH}_{3} \mathrm{CN}\right)\left(\mathrm{NH}_{3}\right) \mathrm{H}^{+}$

$90.9 \%\left(\mathrm{CH}_{3} \mathrm{COCH}_{3} \mathrm{XNH}_{3}\right) \mathrm{H}^{+}$and $4.5 \%\left(\mathrm{CH}_{3} \mathrm{OCH}_{3}\right)\left(\mathrm{NH}_{3}\right) \mathrm{H}^{+}$.

${ }^{9} 9.5 \%\left(\mathrm{CH}_{3} \mathrm{OCH}_{2} \mathrm{CH}_{2} \mathrm{OCH}_{3} \mathrm{KNH}_{3}\right) \mathrm{H}^{+}$. 
alkyl amines are unable to insert because they have no $\mathrm{N}-\mathrm{H}$ bonds. This is consistent with the experimental results. Methanol is able to insert because of its $\mathrm{O}-\mathrm{H}$ bond, and its reaction product with $\left(\mathrm{CH}_{3} \mathrm{CN}\right)_{2} \mathrm{H}^{+}$ (Scheme II) leads to a well known closed-shell ion [4, 27].

The dimer $\left(\mathrm{CH}_{3} \mathrm{OCH}_{3}\right)_{2} \mathrm{H}^{+}$demonstrates association for methanol as the major reaction channel and switching as the minor channel. The latter is 4.4 $\mathrm{kcal} / \mathrm{mol}$ endothermic, whereas the former is -18.1 $\mathrm{kcal} / \mathrm{mol}$ exothermic $[8,13]$, but may involve a fairly large insertion barrier because the overall reactivity is very low (Table 3 ). The protonated ether dimer does not demonstrate the insertion reaction for ammonia, methyl amine, or dimethyl amine. Apparently the insertion barrier for these molecules is too high to allow competition with the switching reactions. We ascribe the barrier to steric hindrance.

The importance of the association-insertion mechanism led us to test our assumptions further by reacting a series of protonated dimers with ammonia. The results are summarized in Table 5. Dimers such as $(\mathrm{HCOOH})_{2} \mathrm{H}^{+}$, which ran hydrogen bond at the periphery, give a pure switching reaction with ammonia. A suggested mechanism is given in Scheme III. The ammonia can attach to an outer $\mathrm{O}-\mathrm{H}$ proton and does not have to attack the $\mathrm{O}-\mathrm{H}-\mathrm{O}$ bridge for switching to occur. The proton of the $\mathrm{O}-\mathrm{H}-\mathrm{O}$ bridge binds to one of the formic acid molecules, the second formic acid molecule is evaporated, and an $\mathrm{O}-\mathrm{H}-\mathrm{N}$ bridge is formed instead. Protonated dimers of acctonitrile, acetone, acetaldehyde, and ethyl acetate and mixed dimers of acetonitrile and acetone all demonstrate the association-insertion channel, as expected. Pure and mixed dimers that involve dimethyl ether or diethyl ether do not demonstrate the association channel with ammonia. Switching probably takes place via attack of the ammonia on the central $\mathrm{O}-\mathrm{H}-\mathrm{O}$ bridge, but there is no rearrangement from a centrally proton-binding trimer to a trimer that has $\mathrm{NH}_{4}^{+}$as the central ion. To the best of our knowledge, such ions have not been detected previously under photoionization of neutral clusters or under chemical ionization. An interesting dimer that does demonstrate the insertion mechanism is $\left(\mathrm{CH}_{3} \mathrm{OCH}_{2} \mathrm{CH}_{2} \mathrm{OCH}_{3}\right)_{2} \mathrm{H}^{+}$. These results suggest the formation of a stable bicyclic structure 1. Another dimer that demonstrates the insertion mechanism is $\left(\mathrm{C}_{4} \mathrm{H}_{8} \mathrm{O}\right)_{2} \mathrm{H}^{+}$(tetrahydrofuran). This observation substantiates the idea of steric hindrance in the case of dimethyl ether and diethyl ether, which is lifted in the case of tetrahydrofuran.

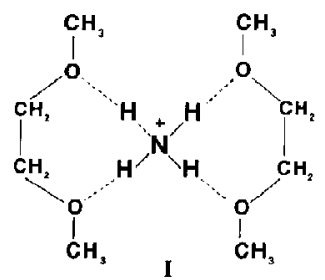

\section{Acknowledgments}

This research was supported by a grant from the United States/Israel Binational Science Foundation (BSF), Jerusalem. Professor A. W. Castleman, Jr. serves as the American Cooperative Investigator of this grant. We thank Dr. M. Mautner for very helptul comments and for providing us with unpublished results, and Professor A. Mandelbaum for suggesting the experiment with the proton-bound tetrahydrofuran dimer.

\section{References}

1. Viggiano, A. A.; Dale, F.; Paulson, J. F. I. Chem. Phys. 1988, 88, 2469-2477.

2. Morris, R. A.; Viggiano, A. A.; Paulson, J. F.; Henchman, M. J. J. Am. Chem. Soc. 1991, 113, 5932-5936.

3. Hierl, P. M.; Ahrens, A. F.; Henchman, M.; Viggiano, A. A.; Paulson, J. F. Int. J. Mass Spectrom. Ion Process. 1987, 81, 101-122.

4. Feng, W. Y.; Iraqi, M.; Lifshitz, C. J. Phys. Chem. 1993, 97, 3510-3514.

5. Yamabe, S.; Minato, T.; Hirao, K. Can. J. Chem. 1983, 67, $2827-2828$

6. Aviyente, V.; Varnali, T. J. Mol. Struct. 1992, 277, 285-292.

7. Deakyne, C. A.; Meot-Ner (Mautner), M.; Campbell, C. L.; Hughes, M. G.; Murphy. S. P. J. Chem. Phys. 1986, 84, $4958-4969$.

8. Hiraoka, K.; Grimsrud, E. P.; Kebarle, P. I. Am. Chem. Soc. 1974, 96, 3359-3364.

9. Wei, S.; Tzeng, W. B.; Castleman, A.W., Jr. J. Phys. Chem. 1991, 95, 5080-5085.

10. Mestdagh, J. M.; Binet, A.; Sublemontier, O. J. Phys. Chem 1989, 93, 8300-8303.

11. Grimsrud, E. P.; Kebarle, P. I. Am. Chem. Soc. 1973, 95, 7939-7943.

12. Tzeng, W. B.; Wei, S.; Castleman, A. W., Jr. Chem. Phys. Lett. 1990, 168, 30-36.

13. Meot-Ner (Mautner), M. J. Am. Chem. Soc. 1992, 114, 3312-3322.

14. Meot-Ner (Mautner), M.; Sieck, L. W. J. Am. Chem. Soc. 1991 , $113,4448-4460$.

15. Lias, S. G.; Liebman, J. F.; Levin, R. D. J. Phys. Chem. Ref. Dat $a$ 1984, 13, 695-808.

16. Arijs, E.; Nevejans, D.; Ingels, J. Int. J. Mass Spectrom. Ion Process. 1987, 81, 15-31.

17. Arnold, F.; Knop, G. Int. J. Mass Spectrom. Ion Process. 1987, 81, 33-44.

18. Iraqi, M.; Peres, M.; Petrank, A; Lifshitz, C. Rapid Commun. Mass Spectrom., 1990, 4, 323-326.

19. Viggiano, A. A.; Morris, R. A.; Deakyne, C. A.; Dale, F.; Paulson, J. F. J. Phys. Chem. 1990, 94, 8193-8197.

20. Bohme, D. K. In lonic Processes in the Gas Phase; Almoster Ferreira, M. A., ed.; Reidel: Dordrecht, 1982.

21. Iraqi, M.; Petrank, A.; Peres, M.; Lifshitz, C. Int. J. Mass Spectrom. Ion Process. 1990, 100, 679-691.

22. McEwan, M. J.; Denison, A. B.; Anicich, V. G.; Huntress, W.T., Jr., Int. J. Mass Spectrom. Ion Process. 1987, 81, 247-257.

23. Kofel, P.; McMahon, T. B. J. Phys. Chem. 1988, 92, 6174-6176.

24. Anicich, V. G.; Sen, A. D.; Huntress, W. T.; McEwan, M. J. I. Chem Phys. 1991, 94, 4189-4194.

25. Su, T.; Chesnavich, W. J. I. Chem. Phys. 1982, 76, 5182-5185.

26. Ridge, D. P. In Structure / Reactivity and Thermochemistry of Ions; Ausloos, P.; Lias, S.G., eds.; Reidel: Dordrecht, 1987, pp. 1-21. 
27. El-Shall, M. S.; Olafsdottir, S. R.; Meot-Ner (Mautner), M.; Sieck, L. W. Chem. Phys. Lett. 1991, 185, 193-198.

28. Meot-Ner (Mautner), M. J. Am. Chem. Soc. 1984, 106, 1257-1264.

29. Meot-Ner (Mautner), M. J. Am. Chem. Soc. 1984, 106, 1265-1272.

30. Sieck, L. W.; Mautner (Meot-Ner), M. J. Phys. Chem. 1982, 86, 3646-3650.

31. Meot-Ner (Mautner), M. I. Phys. Chem. 1991, 95, 6580-6585.
32. Olmstead, W. N.; Brauman, J. I. I. Am. Chem. Soc. 1977, 99, 4219-4228.

33. Speranza, M. Int. J. Mass. Spectront. Ion Process. 1992, 118 / 119, 395-447.

34. Tzeng, W. B.; Wei, S.; Castleman, A. W., Ir. Chent. Phys. Lett. $1990,766,343-352$.

35. Tzeng, W. B.; Wei, S.; Castleman, A. W., Jr. J. Phys. Chem. 1991, $95,5757-5763$.

36. Li, X.; Harrison, A. G. J. Am. Chem. Soc. 1993, 115, 6327-6332. 